\title{
Comparison and evaluation of Renibacterium salmoninarum quantitative PCR diagnostic assays using field samples of Chinook and coho salmon
}

\author{
Todd A. Sandell ${ }^{1, *}$, Kym C. Jacobson ${ }^{2}$ \\ ${ }^{1}$ Department of Microbiology, Oregon State University, Corvallis, Oregon 97331, USA \\ ${ }^{2}$ Northwest Fisheries Science Center, NOAA, Newport, Oregon 97365, USA
}

\begin{abstract}
Renibacterium salmoninarum is a Gram-positive bacterium causing bacterial kidney disease (BKD) in susceptible salmonid fishes. Several quantitative PCR (qPCR) assays to measure $R$. salmoninarum infection intensity have been reported, but comparison and evaluation of these assays has been limited. Here, we compared 3 qPCR primer/probe sets for detection of $R$. salmoninarum in field samples of naturally exposed Chinook and coho salmon first identified as positive by nested PCR (nPCR). Additional samples from a hatchery population of Chinook salmon with BKD were included to serve as strong positive controls. The 3 qPCR assays targeted either the multiple copy major

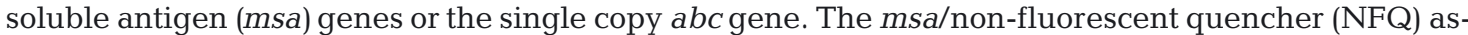
say amplified $R$. salmoninarum DNA in $53.2 \%$ of the nPCR positive samples, whereas the $a b c / N F Q$ assay amplified $21.8 \%$ of the samples and the abc/TAMRA assay $18.2 \%$. The enzyme-linked immunosorbent assay (ELISA) successfully quantified only $16.4 \%$ of the nPCR positive samples. Although the msa/NFQ assay amplified a greater proportion of nPCR positive samples, the $a b c / \mathrm{NFQ}$ assay better amplified those samples with medium and high ELISA values. A comparison of the geometric mean quantity ratios highlighted limitations of the assays, and the $a b c / N F Q$ assay strongly amplified some samples that were negative in other tests, in contrast to its performance among the sample group as a whole. These data demonstrate that both the msa/NFQ and $a b c / N F Q$ qPCR assays are specific and effective at higher infection levels and outperform the ELISA. However, most pathogen studies will continue to require multiple assays to both detect and quantify $R$. salmoninarum infection.
\end{abstract}

KEY WORDS: Renibacterium salmoninarum • Quantitative PCR · Assay comparison · Natural infection Resale or republication not permitted without written consent of the publisher

\section{INTRODUCTION}

Renibacterium salmoninarum infection is common among free-ranging and captive salmonid populations and causes bacterial kidney disease (BKD) in susceptible fish. BKD typically causes a chronic disease but can also lead to high mortality, particularly in high density rearing situations. The bacterium can be transmitted either vertically from infected females or horizontally (Balfry et al. 1996, McKibben \& Pascho 1999). Transmission from hatchery to naturally reproducing populations, and vice versa, has been documented (Mit- chum \& Sherman 1981). As efforts at controlling R. salmoninarum via vaccination have met with limited success in Pacific salmon (Kaattari \& Piganelli 1997, Piganelli et al. 1999, Alcorn et al. 2005), antibiotic treatment and broodstock culling of highly infected egg lots at spawning are the primary methods for mitigating the disease. Thus, efforts to control the spread of the pathogen require the availability of sensitive and reliable detection assays.

Bacterial culture has been a standard assay for many years due to its sensitivity and because a positive result indicates live Renibacterium salmoninarum cells, in- 
stead of cellular products, such as the major soluble antigen (msa), that may persist after cell death (Pascho et al. 1997). However, while the reagents used in this procedure are inexpensive, it is time consuming (plates need to be cultured for several weeks before $R$. salmoninarum colonies are detected) and does not lend itself well to large sampling studies, such as broodstock screening efforts at salmon hatcheries. In addition, a number of reports in the literature suggest that newer assays may provide greater sensitivity and faster results (Pascho \& Mulcahy 1987, Gudmundsdóttir et al. 1993, Jansson et al. 1996, Miriam et al. 1997).

A number of non-culture diagnostic tests have been developed that target either Renibacterium salmoninarum antigens or nucleic acids. The enzyme-linked immunosorbent assay (ELISA) has been widely used at salmon hatcheries in the Pacific Northwest (USA) for broodstock screening for $R$. salmoninarum due to its ability to test many samples simultaneously and to quantify the level of bacterial antigen. The ELISA also has drawbacks, including limited sensitivity, crossreactivity (Wood et al. 1995, Kim et al. 2007), and variability between antibody lots that can make data comparison between laboratories difficult. For these reasons, nested PCR (nPCR) (Chase \& Pascho 1998) has become widely used for the detection of $R$. salmoninarum outside of the hatcheries. Though extremely sensitive, nPCR does not supply a quantitative output of infection intensity and may detect DNA from nonviable bacteria (Josephson et al. 1993). It is also prone to false positives because the amplified product (an msa gene segment) poses a contamination risk in ongoing assays.

Newer molecular techniques, such as reversetranscriptase PCR (RT-PCR), detect and amplify recently transcribed gene products (RNA), thus only quantifying an active infection (although detection of mRNA does not necessarily indicate protein translation). However, this requires the isolation and preservation of RNA, which can be difficult in the field, and adds the cost and effort of validating a 2-step reaction process, first to convert mRNA to CDNA, and then to amplify the cDNA using a standard quantitative PCR (qPCR). Standard DNA-based qPCR can detect nonviable bacterial DNA, as can the nPCR, but it offers other advantages. The DNA-based qPCR allows the detection and quantification of the number of target genes in a sample ('mean quantity') with easier sample storage and preparation, a short processing time (in comparison to culture or the fluorescent antibody technique, FAT), and the ability to quickly analyze a large number of samples. Recently, a number of DNA- and RNA-based qPCR assays have been reported (Powell et al. 2005, Chase et al. 2006, Bruno et al. 2007, Suzuki \& Sakai 2007, Jansson et al. 2008, Halaihel et al. 2009). To date, however, there have been no direct comparisons of these various qPCR assays for the detection of Renibacterium salmoninarum in Chinook Oncorhynchus tshawytscha and coho O. kisutch salmon, and only limited comparison with other standard diagnostic tests (e.g. ELISA or nPCR).

The qPCR assays used in this study target either the multiple copy msa genes (Chase et al. 2006) or the single copy $a b c$ transporter permease $(a b c)$ gene (Rhodes et al. 2006) of Renibacterium salmoninarum. The 2 assays that target the $a b c$ gene differ in probe chemistry. The first uses a standard TAMRA probe quencher while the other utilizes a non-fluorescent quencher (NFQ) and a minor groove-binding (MGB) linker that binds to the double-stranded DNA helix between the phosphate-sugar backbones. The major goal of this study was to evaluate the $a b c$ qPCR assay and to compare it with the msa qPCR using juvenile Chinook and coho salmon naturally infected with $R$. salmoninarum, as well as some heavily infected hatchery fish that served as strong positives. Here, we report the comparative specificity, repeatability and reproducibility of the $R$. salmoninarum qPCR assays, including evaluation against the widely used $R$. salmoninarum ELISA assay, which provided an indication of infection severity, and the nPCR as the reference measure of $R$. salmoninarum exposure. This study utilized guidelines set forth by the World Organization for Animal Health (Belak \& Thoren 2006) for assay validation. Additionally, Bustin et al. (2009) presented a framework for nomenclature and standardized reporting with regard to qPCR assays to avoid confusion; we have incorporated these suggestions where possible. The results presented here will aid other researchers in choosing among these techniques for $R$. salmoninarum detection and quantification in future research.

\section{MATERIALS AND METHODS}

Sample collection and DNA extraction. The majority of fish used in this study were juvenile Chinook and coho salmon captured in the nearshore off the coasts of Oregon and Washington. Immediately following capture via surface trawl, the fish were sorted, placed on ice, identified to species and given a unique sample number. Fish were then frozen at $-80^{\circ} \mathrm{C}$ until a later date, when necropsies were performed and the anterior kidney excised, placed in a $2 \mathrm{oz}$ (5.67 g) Whirlpak bag, and refrozen at $-80^{\circ} \mathrm{C}$ (the posterior kidneys were removed for Nanophyetus salmincola analysis). During necropsy, instruments were placed in a $20 \%$ bleach solution between fish for at least $2 \mathrm{~min}$ and rinsed twice in water to prevent cross-contamination of DNA samples. 
A second group of juvenile Chinook salmon $(n=18)$ were obtained from the Oregon Department of Fish and Wildlife (ODFW) Cole River Hatchery (CRH) (Trail, Oregon). These fish were provided by the ODFW Fish Health Unit (Corvallis, Oregon) and were sampled as mortalities at the hatchery; kidneys were removed and stored at $-20^{\circ} \mathrm{C}$ until analyzed as described below. Most of the CRH kidneys had white pustules indicative of clinical BKD.

Anterior kidney samples were thawed and homogenized with a rolling pin while still in the Whirlpak bag; $25 \mathrm{mg}$ of kidney tissue $( \pm 2.5 \mathrm{mg})$ was removed with a sterile plastic spatula and placed into a $1.5 \mathrm{ml}$ microcentrifuge tube. The work area and rolling pin were frequently bleached with a $20 \% \mathrm{NaClO}_{3}$ solution and care was taken to prevent cross-contamination of samples. Suggested guidelines from the American Fisheries Society Blue Book for quality assurance/quality control were followed (AFS-FHS 2007). Kidney tissues from black rockfish Sebastes melanops were included with each set of DNA extractions (36 samples per set) as a negative extraction control. DNA extraction was conducted using the DNeasy Tissue Kit (single tubes) following the manufacturer's (Qiagen) instructions for Gram-positive bacteria. DNA was eluted with $200 \mu \mathrm{l}$ of Buffer $\mathrm{AE}$ heated to $70^{\circ} \mathrm{C}$. Following elution, samples were either run immediately or stored at $-80^{\circ} \mathrm{C}$ until analyzed.

Nested PCR (nPCR). To detect the presence of Renibacterium salmoninarum, all samples were initially tested via the nPCR protocol of Chase \& Pascho (1998). The thermocycling regime was slightly modified to optimize results on our thermocycler, an MJ Research P100, as follows: $88^{\circ} \mathrm{C}$ for 3 minutes, $94^{\circ} \mathrm{C}$ for $2 \mathrm{~min}$, then 30 cycles of $94^{\circ} \mathrm{C}$ for $30 \mathrm{~s}, 60^{\circ} \mathrm{C}$ for $1 \mathrm{~min}$, and $72^{\circ} \mathrm{C}$ for $1 \mathrm{~min}$. Reagent concentrations and primers were unchanged. The protocol was also modified to allow the use of 96-well PCR plates (Fisher Scientific \#05-500-48) after a trial was conducted to test assay sensitivity using several different brands of PCR plates (data not shown). DNA concentration was not adjusted prior to nPCR analysis. All plates contained positive controls, no template controls, and the $R$. salmoninarum-negative DNA extraction controls. Amplified samples were subjected to electrophoresis on $1 \%$ agarose gels and visualized by staining with ethidium bromide, then photographed under UV light. Only samples testing positive with $\mathrm{nPCR}$, and negative extraction controls, were further analyzed by ELISA and qPCR. A total of 220 DNA samples containing $R$. salmoninarum DNA detected by $\mathrm{nPCR}$ were used in this study (including $18 \mathrm{CRH}$ samples).

Enzyme-linked immunosorbent assay (ELISA). Samples that were positive with the nPCR were tested for Renibacterium salmoninarum antigen by the ELISA II method (Pascho \& Mulcahy 1987), a widely used standard reference assay for quantifying the degree of $R$. salmoninarum infection. The resulting optical densities (OD) were binned into 4 categories: background $(\mathrm{OD}<0.08)$, low $(0.081<\mathrm{OD}<0.199)$, medium $(0.199<$ $\mathrm{OD}<0.499$ ), and high (OD $>0.499)$.

Quantitative PCR. All qPCR primer and probes sequences are provided in Table 1. Initially, we compared 2 different probes for the $a b c$ qPCR assays. The first $a b c$ probe was labeled with a 5' FAM reporter and 3' TAMRA quencher as developed by Rhodes et al. (2006). The second probe was modified to contain a MGB linker and a non-fluorescent quencher. The $a b c$ primers were not modified from Rhodes et al. (2006). The msa assay was performed as reported by Chase et al. (2006) but the probe was also modified with a MGB linker and NFQ quencher. Plasmid DNA encoding either the $a b c$ or msa genes were used as absolute standards (the $a b c$ plasmid was supplied by L. Rhodes; the msa plasmid was supplied by K. True). The plasmid DNA was diluted in 10-fold increments in a range of $10^{8}$ to $10^{1}$ copies and used to create a standard curve. Fresh standards were made each day from a concentrated stock stored at $-80^{\circ} \mathrm{C}$ (Rhodes et al. 2006). Prior to the qPCR, DNA was quantified using the PicoGreen assay (Invitrogen) using a Victor plate fluorometer (Perkin Elmer). Since the samples consisted of DNA

Table 1. Primer and probe sequences used for qPCR detection of Renibacterium salmoninarum. Note that some of the probes used in this study utilized a minor groove-binding (MGB) linker with a non-fluorescent quencher (NFQ) that differ from those used in the original publications

\begin{tabular}{|llll|}
\hline qPCR target & Name & Sequence (5' to 3') & Source \\
\hline msa genes & RS1238 & GTG ACC AAC ACC CAG ATA TCC A & Chase et al. (2006) \\
msa gene & RS1307 & TCG CCA GAC CAC CAT TTA CC & Chase et al. (2006) \\
msa genes & RS1262.NFQ probe ${ }^{\text {a }}$ & FAM-CAC CAG ATG GAG CAA C-MGB/NFQ & Chase et al. (2006) \\
abc gene & ABCtransfor2 & CTA AAC GAT TTC CCG GTC AA & Rhodes et al. (2006) \\
$a b c$ gene & ABCtransrev2 & GAT TTT GCC TGC TGG TAT TTC C & Rhodes et al. (2006) \\
$a b c$ gene & ABCtrans probe & FAM-AAG CGC CAG CAG TCG ACG GC-TAMRA & Rhodes et al. (2006) \\
$a b c$ gene & ABC.NFQ probe ${ }^{\mathrm{a}}$ & FAM-AAG CGC CAG CAG TCG ACG GC-MGB/NFQ & Rhodes et al. (2006) \\
an the original publication, 3' end of the probe was labeled with TAMRA & \\
\hline
\end{tabular}


extractions from equal weights of kidney tissue, we originally assumed that they would have roughly equivalent amounts of DNA present. However, DNA concentration varied widely following elution from the Qiagen DNeasy kits (data not shown). To ensure that equal amounts of DNA were present in each reaction, samples with low DNA yields were concentrated using a speed vacuum procedure (volume was reduced by 2/3) and all DNA samples were normalized to $20 \mathrm{ng}$ $\mathrm{Hl}^{-1}$ using a Biomek FX robotic workstation (Beckman Coulter). All experimental samples, negative DNA extraction controls and standards were run in duplicate wells; 4 wells of no template controls (NTC) were included on each plate. Quantitative PCRs were conducted using the Applied Biosystems (ABI) 7500 instrument and data analyzed with the sequence detection software (V.1.22). All dual-labeled probes and the Taqman Universal Master Mix, qPCR plates and optical covers were purchased from $\mathrm{ABI}_{\text {; }}$ primers were purchased from Integrated DNA Technologies. All assays contained $900 \mathrm{nM}$ primers, $200 \mathrm{nM}$ probe and a total of $100 \mathrm{ng}$ template DNA.

Samples with a 'quantification cycle $\left(\mathrm{C}_{\mathrm{q}}\right)$ value' (Bustin et al. 2009) over 38 were considered negative because amplification in this range is near the theoretical lower limit of detection (less than 10 copies of the genome in the sample) (Note: ' $\mathrm{C}_{\mathrm{q}}$ ' is referred to as ' $\mathrm{C}_{\mathrm{T}}$ ' in ABI software). Each time a segment of target DNA is amplified in the qPCR assay, a sequence-specific probe begins to fluoresce as the probe quencher (NFQ) is deactivated; thus the level of fluorescence is correlated to the amount of target DNA in the sample. Samples with lower initial target DNA concentrations require more amplification cycles to generate enough fluorescence to cross the threshold quantification value; thus, for the $\mathrm{qPCR}$, a higher $\mathrm{C}_{\mathrm{q}}$ value is indicative of a lower initial target DNA concentration.

Evaluation of specificity, repeatability and reproducibility. An initial evaluation of the sensitivity of the $a b c /$ TAMRA and $a b c /$ NFQ qPCR assays was done by comparing the plasmid standard curves and reaction efficiencies. To test the analytical specificity of the $a b c$ qPCR assays, we extracted DNA from putative uninfected coho salmon, Chinook salmon and black rockfish (the salmon samples were from disease-free populations and were negative in repeated tests with $\mathrm{nPCR})$. Seed stocks of phylogenetically related bacteria or common bacterial fish pathogens (see Table 2) were cultured on American Type Culture Collection (ATCC)-recommended agar and harvested via scraping and sterile water rinse. The wash from 3 plates of each species were combined and centrifuged for $10 \mathrm{~min}$ at $12000 \times g_{i}$ the pellet was then divided into 5 microcentrifuge tubes and digested in lysis buffer. DNA extraction proceeded as for the study samples using Qiagen protocols (see above), and the DNA concentration was normalized to $20 \mathrm{ng} \mathrm{ml}^{-1}$ prior to qPCR. Renibacterium salmoninarum (ATCC 33209) served as a positive control.

Repeatability ('intra-assay variance') (Bustin et al. 2009) and reproducibility ('inter-assay variance') of the qPCRs was tested by comparing replicates of the same samples. Select samples with adequate DNA quantities $(\mathrm{n}=6)$ were run in 4 to 8 replicate wells on the same qPCR plate to test intra-assay variance. This procedure was repeated on 3 independent assay plates to test inter-assay variability on consecutive days.

Statistical analysis. Calculations of $\mathrm{C}_{\mathrm{q}}$ value and mean quantity, as well as standard deviations, were generated by the ABI software provided with the ABI 7500 optical thermocycler. The mean quantity is the number of target genes amplified in the sample, derived by comparing the $\mathrm{C}_{\mathrm{q}}$ value of a sample with the standard curve, which contains known numbers of the target gene. Thus, for a single copy target gene the mean quantity is a direct estimate of the number of bacteria present in the sample. Calculations of geometric mean quantities and the coefficient of variation (CV: the ratio of the standard deviation to the mean) were done in Microsoft Excel. Repeatability comparisons of differences in the $\mathrm{C}_{\mathrm{q}}$ values were performed using the non-parametric Sign test. Comparisons of $\mathrm{C}_{\mathrm{q}}$ values for sample reproducibility (between plates) were performed using the Kruskal-Wallis nonparametric ANOVA because of the non-normal distribution of these data. Differences in the detection performance of the qPCR assays were compared with a chi-square test using StatView software (v. 1998, SAS Institute). In all cases, significance was defined as $\mathrm{p} \leq$ 0.05 .

Visual data comparisons and regression $\mathrm{r}^{2}$ values were calculated using Tableau software (v. 2008, Tableau Software). Samples which did not amplify were arbitrarily assigned a $\mathrm{C}_{\mathrm{q}}$ of 42 for clarification, since the $\mathrm{C}_{\mathrm{q}}$ has an inverse relationship with the quantity of gene product present (i.e. a 'low' $\mathrm{C}_{\mathrm{q}}$ indicates the presence of more gene copies than a 'high' value). Throughout this paper we refer to samples falling within the given ranges as having the following $\mathrm{C}_{\mathrm{q}}$ 'scores': 'high' $\left(14<\mathrm{C}_{\mathrm{q}}<20\right)$, 'medium' $\left(20.01<\mathrm{C}_{\mathrm{q}}<\right.$ $30)$, and 'low' $\left(30.01<\mathrm{C}_{\mathrm{q}}<38\right)$.

\section{RESULTS}

\section{Initial sample selection}

A total of 202 samples were classified as positive for Renibacterium salmoninarum by nPCR and were included in this qPCR evaluation study. We also 
obtained kidney samples from 18 Chinook salmon with clinical signs of BKD from the CRH (ODFW), all of which tested positive by $\mathrm{nPCR}$, providing a total of $220 \mathrm{nPCR}$ positive samples to be compared in further analyses.

\section{ELISA}

The ELISA detected quantifiable levels of Renibacterium salmoninarum antigen in $16.4 \%$ of the samples previously determined to be positive by the nPCR ( $\mathrm{n}=36 / 220$ ). Of the ELISA positives, we binned $13.9 \%$ as highly infected (OD > 0.499), $2.7 \%$ as moderately infected $(0.199<\mathrm{OD}<0.499)$, and $0.9 \%$ as having a low infection level $(0.081<\mathrm{OD}<0.199) ; 82.5 \%$ were at background levels (OD < 0.08). All of the qPCR assays amplified the majority of the ELISA positive samples. The $a b c / N F Q$ qPCR identified $88.9 \%$ (32/36) as positive, the abc/TAMRA qPCR detected $72.2 \%(26 / 36)$, and the msa/NFQ qPCR detected $94.4 \%(34 / 36)$. All but 2 of the $\mathrm{CRH}$ samples were binned as highly infected by ELISA; the remaining 2 were at background OD levels. The ELISA detected 5 samples (from the naturally infected salmon) as positive that were not amplified by any of the 3 qPCR assays ('unique positives'): 2 of these were in the low ELISA range, 1 was medium, and 2 were in the high range. All of the negative controls were also negative with the ELISA.

\section{qPCR specificity}

Initial tests showed that the $2 a b c / N F Q$ qPCR primer/probe sets did not amplify either Chinook or coho salmon Renibacterium salmoninarum-negative DNA, any of the 13 other bacterial species tested (Table 2), or any of the negative controls.

\section{qPCR repeatability and reproducibility}

There was no statistical difference either within or among the plates in the repeatability and reproducibility study for either $\mathrm{C}_{\mathrm{q}}$ values or geometric mean quantities (see Appendix 1). Although there were differences in the quantities of the $a b c$ gene detected between the 6 different samples, these were consistent for each sample.

\section{Preliminary comparison of the qPCR assays}

The samples analyzed with each of the 3 primer/ probe sets were run on 5 qPCR plates. Mean reaction efficiencies $\left(E=10^{(-1 / \text { slope })}-1\right)$ for the 3 assays were all similar and approximately $100 \%$. Regression values from the standard curves exceeded 0.99 for all assays. Of the 202 samples detected as positive by the nPCR, $44.5 \%$ were negative in all 3 qPCR assays ( $\mathrm{n}=98$ ).

The $m s a / N F Q$ qPCR was the most sensitive of the 3 assays, detecting $53.2 \%(\mathrm{n}=117)$ of the samples testing positive with the nPCR (Table 3). Many of these were near the limit of detection, which resulted in the msa/NFQ qPCR assay having the highest average $\mathrm{C}_{\mathrm{q}}$ value (32) and the highest percentage of nonreproducible amplification (samples detected in only 1 of the 2 wells; $34.2 \%$ ) (Table 3 ). A majority (63\%) of the samples amplified by this assay had a $\mathrm{C}_{\mathrm{q}}$ value in the range of 35 to 38 ; the mean quantity of the msa

Table 3. Comparison of the percentage of samples detected, mean quantification cycle $\left(\mathrm{C}_{\mathrm{q}}\right)$ values, and coefficients of variation for the 3 qPCR assays. Both field samples $(n=202)$ and Cole River Hatchery fish $(n=18)$ are included

\begin{tabular}{|lccc|}
\hline Summary & $a b c /$ & $a b c /$ & $m s a /$ \\
& NFQ & TAMRA & NFQ \\
\hline \% positive by the assay & $\mathbf{2 1 . 8}$ & $\mathbf{1 8 . 2}$ & $\mathbf{5 3 . 2}$ \\
\% with only 1 well detected & 14.6 & 17.5 & 34.2 \\
Average $C_{\mathrm{q}}$ & 24.6 & 27.4 & 32.0 \\
Coefficient of variation (CV) & 20.1 & 26.3 & 28.7 \\
\hline
\end{tabular}


gene detected in these samples was very low (5.17). With all of the positive samples included, the msa/NFQ assay had the second highest mean quantity $\left(1.5 \times 10^{2}\right)$ and the highest CV (28.7).

The $a b c / N F Q$ qPCR detected $21.8 \%(n=48)$ of the nPCR positive samples, but had the lowest average $\mathrm{C}_{\mathrm{q}}$ value (24.6), the highest geometric mean quantity $\left(4.1 \times 10^{3}\right)$ and the lowest CV (20.1) of the 3 assays. It also had the lowest number of samples with nonreproducible amplification (14.6\%). Fewer samples were quantified in the $\mathrm{C}_{\mathrm{q}}$ range of 35 to $38(20.8 \%)$.

The abc/TAMRA assay detected only $18.2 \%$ of the $n P C R$ positive samples $(n=40)$ and had an average $C_{q}$ value of 27.4. This assay produced the lowest geometric mean quantity (138.4) of the 3 assays, and fell between the others with regard to CV (26.3) and the percentage of non-reproducible amplifications (17.5\%) (Table 3). All CRH Chinook salmon samples had quantifiable Renibacterium salmoninarum DNA levels in the $m s a / N F Q$ and $a b c / N F Q$ assays, but only $77.8 \%$ of the samples amplified with the $a b c / T A M R A$ assay.

Overall, the msa/NFQ assay detected 65 samples that tested negative with the $a b c / N F Q$, while the $a b c$ assay detected 2 samples that tested negative with the msa/NFQ qPCR. A chi-square comparison of the 2 qPCR assays indicated that the $m s a / N F Q$ detected significantly more positive samples than the $a b c / \mathrm{NFQ}$ ( $\mathrm{p}<0.001$ ) and the abc/TAMRA assays $(\mathrm{p}<0.001)$. Based on these results, we selected only the $a b c / \mathrm{NFQ}$ and $m s a / N F Q$ assays for further comparison.

\section{Comparison of the qPCR results with ELISA}

The qPCR assays all quantified more nPCR positive samples than the ELISA. The regression of average $\mathrm{C}_{\mathrm{q}}$ value versus ELISA OD yielded an $\mathrm{r}^{2}$ of 0.786 for the $a b c / N F Q$ assay and 0.903 for the msa/NFQ assay when all positive samples were included (Fig. 1a). However, when only those samples with a medium or higher ELISA OD were included in the regression analysis, the $a b c / N F Q$ assay $r^{2}$ was 0.727 , while that of the msa/ NFQ assay declined to 0.579 (Fig. 1b). Of the samples that were negative by the ELISA ( $\mathrm{n}=184)$, $12 \%$ were positive with the $a b c / \mathrm{NFQ}$ assay and $46.7 \%$ were positive with the $m s a / N F Q$ assay.

To further compare the ELISA and qPCR assays, we examined the ELISA OD values of samples that were binned into ranges of average $\mathrm{C}_{\mathrm{q}}$ scores representing high $\left(\mathrm{C}_{\mathrm{q}}<20\right)$, medium $(20<$ $\left.\mathrm{C}_{\mathrm{q}}<30\right)$ and low $\left(30<\mathrm{C}_{\mathrm{q}}<38\right)$ bins (keep in mind that a lower $\mathrm{C}_{\mathrm{q}}$ value corresponds with a higher gene target quantity, i.e. a more highly infected sample, while the ELISA OD directly correlates with the amount of bacterial antigen present). Only samples positive for both the msa and $a b c$ gene qPCRs were included. For the $a b c / N F Q$ assay, $31.2 \%$ of the samples in the high $\mathrm{C}_{\mathrm{q}}$ range were also high by ELISA, while $14.6 \%$ were low (Table 4). Samples in the medium $\mathrm{C}_{\mathrm{q}}$ bin were equally split in the ELISA bins, but samples in the low ELISA bin were almost evenly spread between the high $(14.6 \%)$, medium $(14.6 \%)$, and low $(16.7 \%) \mathrm{C}_{\mathrm{q}}$ bins. For the msa/NFQ assay, a greater percentage of samples in the high and low $\mathrm{C}_{\mathrm{q}}$ groups matched the corresponding ELISA value bins (Table 4) than for the abc/NFQ assay. Within the high $\mathrm{C}_{\mathrm{q}}$ bin, all of the samples (15.4\% of the total) had high ELISA values, and $70.1 \%$ of the samples with low $\mathrm{C}_{\mathrm{q}}$ values also had low ELISA scores.

\section{Comparative performance of the $a b c / N F Q$ and msa/NFQ qPCR assays}

To test how well the 2 NFQ qPCR assays agreed with each other, the $a b c / \mathrm{NFQ}$ and $m s a / N F Q \mathrm{C}_{\mathrm{q}}$ values were plotted against one another (Fig. 2). In general, samples with low $\mathrm{C}_{\mathrm{q}}$ scores from both qPCR assays (mostly $\mathrm{CRH}$ ) also had high ELISA values (OD = 1.71), while those with high $\mathrm{C}_{\mathrm{q}}$ scores had a lower average OD (0.26). However, the assays were not always in agreement, and did not cluster on the regression line except near the limit of detection $\left(\mathrm{r}^{2}=0.509\right)$. This was largely due to the presence of 8 samples that were positive by the $a b c / N F Q$ assay $\left(\mathrm{C}_{\mathrm{q}} \approx 18\right)$, but were close to the range of detection limit $\left(\mathrm{C}_{\mathrm{q}} \approx 35\right)$ for the msa/NFQ and were below the background level for ELISA (average $\mathrm{OD}=0.071$ ). These samples are highlighted near the top of Fig. 2. To confirm these data, the 8 samples were rerun in the $a b c / N F Q$ assay and yielded similar results.

Table 4. Comparison of quantification threshold $\left(\mathrm{C}_{\mathrm{q}}\right)$ and ELISA optical density (OD) values for the 2 Renibacterium salmoninarum specific qPCRs with nonfluorescent quencher (NFQ) probes. Samples were binned by $\mathrm{C}_{\mathrm{q}}$ value; the percentage of samples in each bin within a certain ELISA OD range was then calculated. ELISA OD bins: low $(<0.199)_{\text {; }}$ medium $(0.199$ to 0.499$)$; high $(>0.499) ; C_{q}$ scores: low (>30.01 to 38$)$; medium (>20.01 to 30$) ;$ high $(<20)$

\begin{tabular}{|lccccc|}
\hline & \multirow{2}{*}{$\mathrm{C}_{\mathrm{q}}$ score } & \multicolumn{3}{c}{ ELISA OD } & \multirow{2}{*}{$\begin{array}{c}\text { Row } \\
\text { total (\%) }\end{array}$} \\
\cline { 3 - 5 } & & Background/low & Medium & High & \\
\hline abc/NFQ & High & 14.6 & 0 & 31.2 & 45.8 \\
Total n $=48$ & Medium & 14.6 & 0 & 12.5 & 27.1 \\
& Low & 16.7 & $4.2 \%$ & 6.2 & 27.1 \\
msa/NFQ & High & 0 & 0 & 15.4 & 15.4 \\
Total $\mathrm{n}=117$ & Medium & 3.4 & 0 & 5.1 & 8.5 \\
& Low & 70.1 & $4.3 \%$ & 1.7 & 76.1 \\
& & & & \\
\hline
\end{tabular}



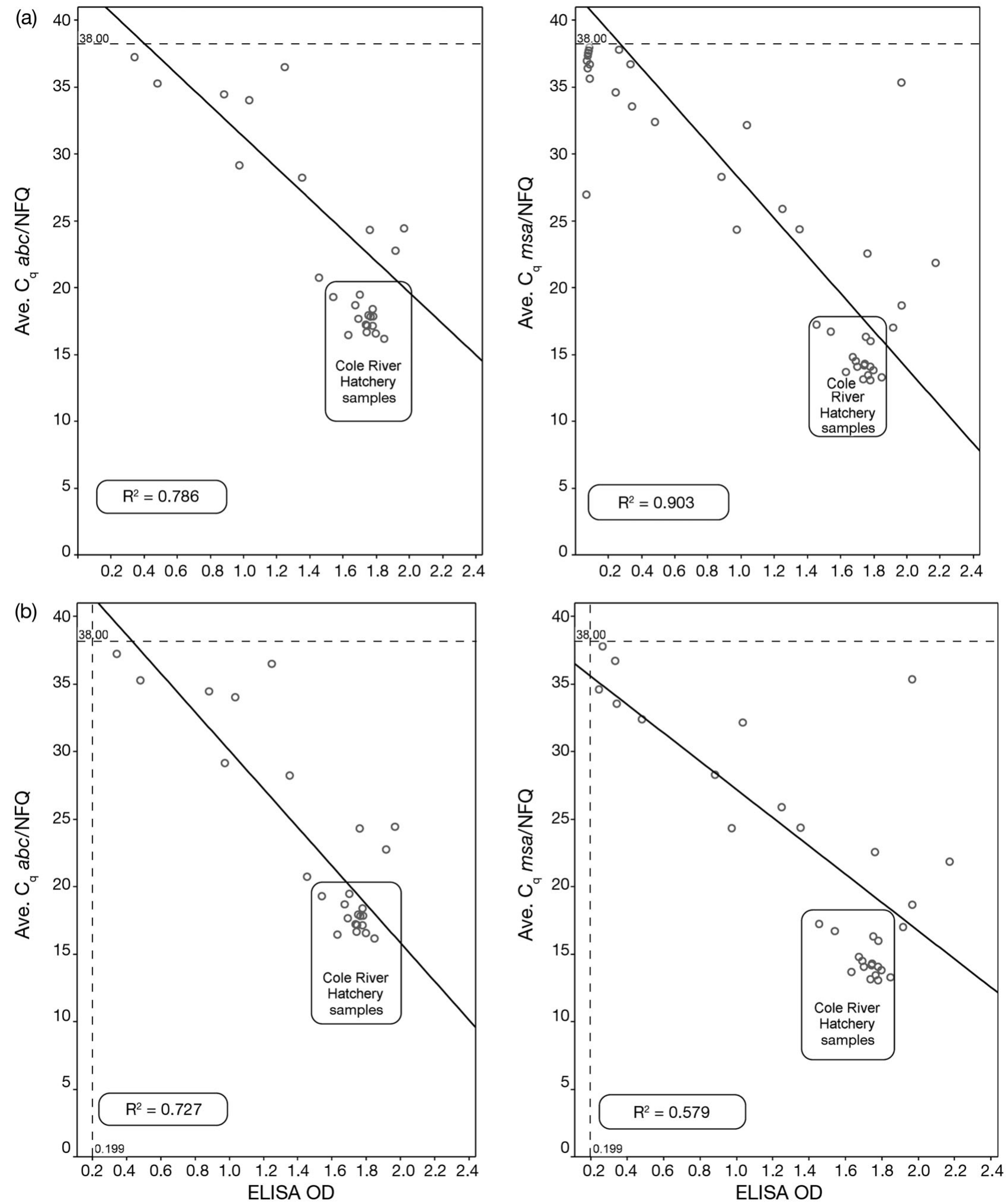

Fig. 1. Quantitative PCR abc/NFQ and msa/NFQ assay quantification cycle $\left(\mathrm{C}_{\mathrm{q}}\right)$ values versus ELISA OD for (a) all positive samples, and (b) for those in the medium-high ELISA OD range only. The horizontal dashed lines indicate the $\mathrm{C}_{\mathrm{q}}$ value limit of 38 ; the vertical dashed lines (b only) indicate the ELISA OD cutoff level (0.199) for medium and highly infected samples 


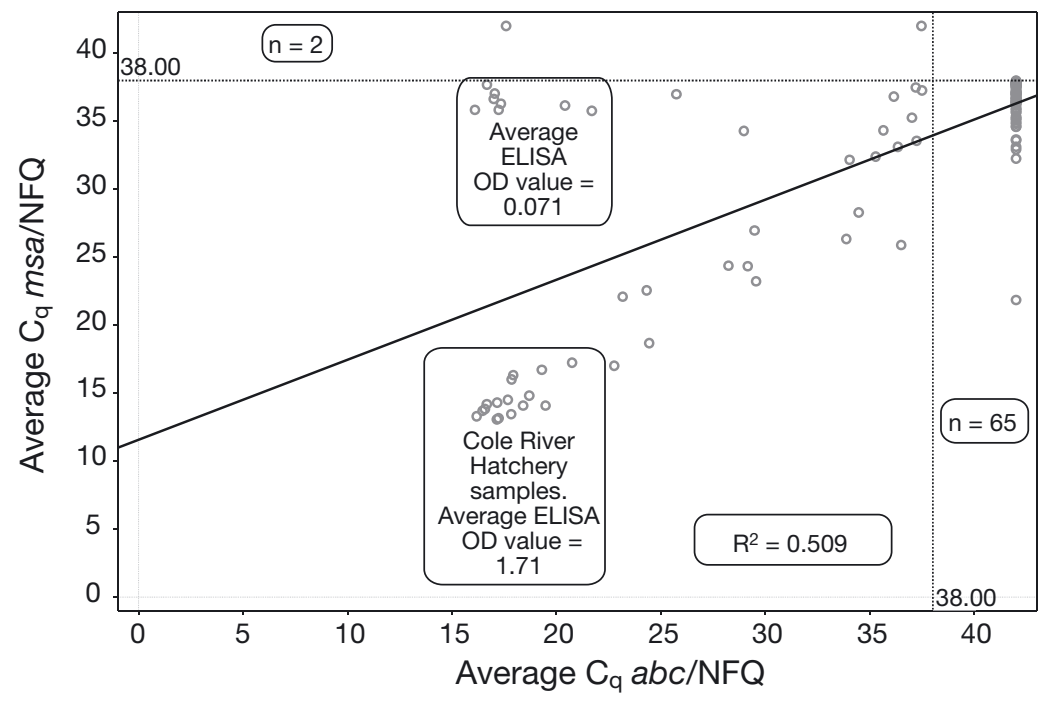

Fig. 2. A regression of msa/NFQ quantification cycle $\left(\mathrm{C}_{\mathrm{q}}\right)$ values versus $a b c / N F Q$ values for all positive samples in the dataset. The horizontal and vertical dotted lines indicate the positive sample $\mathrm{C}_{\mathrm{q}}$ value limit of 38. Average ELISA OD values for subgroups of the sample population are highlighted and the number of samples detected by only 1 of the 2 assays are noted beyond the dotted lines

Table 5. Comparison of geometric mean quantities (Qty), average quantification cycle $\left(\mathrm{C}_{\mathrm{q}}\right)$ values, and their respective ratios for (a) all samples and (b) the Cole River Hatchery (CRH) samples only for both the msa/NFQ and the $a b c / N F Q$ qPCR assays. The ratios provide an indication of reaction efficiency among different subgroups of the sample set

\begin{tabular}{|c|c|c|c|c|}
\hline & $\begin{array}{l}\text { Geometric } \\
\text { mean Qty }\end{array}$ & $\begin{array}{c}\text { Average } \\
\mathrm{C}_{\mathrm{q}}\end{array}$ & $\begin{array}{l}\text { Quantity ratio } \\
(m s a / a b c)\end{array}$ & $\begin{array}{c}\mathrm{C}_{\mathrm{q}} \text { ratio } \\
(\mathrm{msa} / \mathrm{abc})\end{array}$ \\
\hline \multicolumn{5}{|c|}{$\begin{array}{l}\text { (a) Samples that were positive by both assays, not including the CRH } \\
\text { samples }(\mathrm{n}=28)\end{array}$} \\
\hline Avg. for $m s a / N F Q$ & 234.3 & 31.5 & 0.48 & 1.133 \\
\hline Avg. for $a b c / N F Q$ & 483.7 & 27.8 & & \\
\hline Difference & -249.4 & 3.7 & & \\
\hline \multicolumn{5}{|c|}{ (b) As for (a), including only the CRH samples $(\mathrm{n}=18)$} \\
\hline Avg. for $m s a / N F Q$ & 19.205 .953 .1 & 15.9 & 116.7 & 0.820 \\
\hline Avg. for $a b c / N F Q$ & 164.597 .4 & 19.4 & & \\
\hline Difference & 19.041.355.8 & -3.48 & & \\
\hline
\end{tabular}

and the $\mathrm{C}_{\mathrm{q}}$ ratio was 1.13 ; the abc/NFQ assay performed slightly better. When only the CRH samples were included, however, the mean quantity ratio increased to 116.7 , while the $\mathrm{C}_{\mathrm{q}}$ ratio decreased to 0.82 ; the $m s a / N F Q$ assay performed better among the very strong positives (CRH samples). These changes were driven by a large increase in the mean quantity detected by the msa/NFQ assay, which exceeded $1.9 \times 10^{7}$ for the CRH samples (Table 5b).

\section{DISCUSSION}

The msa/NFQ qPCR (Chase et al. 2006) was the most sensitive of the 3 qPCR assays, quantifying 53.2\% of the Renibacterium salmoninarum nPCR positive samples (Table 3). Most of the samples $(63 \%)$ detected by the msa/NFQ assay were near the lower limit of detection $\left(\mathrm{C}_{\mathrm{q}}\right.$ values in the

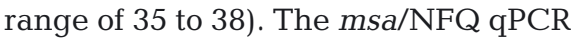
also had the highest percentage of samples detected in only 1 of the 2 wells $(34.2 \%)$. Most of these nonreproducible amplifications were near the lower limit of detection $\left(\mathrm{C}_{\mathrm{q}}\right.$ value cutoff $=38$ ), so the increased variability in this assay was coincident with increased sensitivity, as expected. The $\mathrm{msa} / \mathrm{NFQ}$ assay was also in good agreement with the ELISA (Table 4), and had the highest $r^{2}$ value for the regression of average $C_{q}$ versus ELISA OD when all positive samples were included (Fig. 1b). The higher sensitivity makes the msa/NFQ qPCR a good candidate assay for initial screenings of samples, especially when nPCR or culture will not be used and infection

To further compare the msa/NFQ qPCR to the $a b c / N F Q$ PCR, we first divided the samples into 2 groups: samples positive in both qPCR assays, but without the CRH fish (Table 5a), and the CRH samples alone (Table $5 \mathrm{~b}$ ). We then calculated the geometric mean quantity ratio and $\mathrm{C}_{\mathrm{q}}$ ratio (msa/NFQ value divided by $a b c / N F Q$ value in both cases) for each of these groups. These ratios provide a comparison of amplification efficiency across all levels of infection in the sample subpopulation. For the group with $\mathrm{CRH}$ samples excluded, the mean quantity ratio was 0.48 prevalence is a primary goal. However, because the $R$. salmoninarum genome contains at least 2 to 6 copies of the msa gene (Rhodes et al. 2004), the msa/NFQ assay mean quantity outputs may not directly correlate with the number of bacteria present in the sample. The assay would also be suitable for laboratory studies where the $R$. salmoninarum strain, and thus the number of msa copies, is known.

The $a b c / N F Q$ qPCR assay had excellent repeatability and did not cross-react with the bacteria in our screening panel or Renibacterium salmoninarum- 
negative Chinook or coho salmon genomic DNA. The $a b c / N F Q$ qPCR detected only $21.8 \%$ of the samples that were positive by nPCR but had the highest geometric mean quantity and the lowest coefficient of variation (Table 3 ). It also had the highest average $\mathrm{C}_{\mathrm{q}}$ value of the 3 assays, indicating that the abc/NFQ qPCR assay was better at amplifying samples with medium to high infection levels (based on ELISA values). The assay also performed better than the msa/ NFQ qPCR for the regression of average $C_{q}$ versus ELISA OD when only samples with medium to high ELISA values were included (Fig. 1b). This makes the $a b c / N F Q$ qPCR assay a good candidate for studies where initial prevalence of infection screening will be done via nPCR, and/or when detection of $R$. salmoninarum at infection levels that foreshadow the onset of bacterial kidney disease (based on comparison with the ELISA OD) is the prime concern. For this reason, it may be useful for hatchery broodstock screening programs because it identifies only those fish with medium to high levels of infection, without the drawbacks of the ELISA. The $a b c / N F Q$ assay is the best choice when genome quantification is the primary concern, because the $a b c$ primer set targets a single copy gene.

Some drawbacks with both the $a b c / N F Q$ and msa/NFQ qPCR assays were also identified. Neither of the qPCR assays amplified all of the samples previously identified as positive by nPCR. This was unexpected given the sensitivity reported by Chase et al. (2006), who also tested naturally infected fish. However, the juvenile Chinook salmon used in that study were all from a hatchery population and some had clinical signs of BKD, whereas the fish used in the present study were of unknown origin and had low level infections (at background infection levels with ELISA), with the exception of the $\mathrm{CRH}$ fish included to provide strong positive controls. In addition, the $a b c / \mathrm{NFQ}$ assay strongly amplified a group of 8 samples (in the $\mathrm{C}_{\mathrm{q}}$ range of 15 to 22 ) that were at background ELISA values and only weakly positive with the msa/NFQ qPCR (Fig. 1). The samples were re-tested and the results confirmed, but the possibility exists that the $a b c / N F Q$ qPCR is amplifying a similar gene from another bacterial species in the sample that was not included in our bacterial cross-reactivity panel (Table 2). Attempts at sequencing the product for clarification were unsuccessful and there was not enough DNA remaining in any of the 8 samples to pursue this avenue of investigation. A BLAST search (http://blast. ncbi.nlm.nih.gov/Blast.cgi; accessed November 2009) did not produce any other closely aligned sequences for the $a b c$ gene which were not already included in our cross-reactivity study, although at present there are few fish pathogen sequences in the database.
Another issue was identified when the ratios of average $\mathrm{C}_{\mathrm{q}}$ and geometric mean quantity for the $2 \mathrm{NFQ-}$ based qPCR assays ( $m s a / N F Q$ over $a b c / N F Q$ in all cases) were compared (Table 5). When the CRH samples were excluded, the $a b c / N F Q$ assay outperformed the msa/NFQ, yielding a slightly higher geometric mean quantity and higher average $\mathrm{C}_{\mathrm{q}}$ score, with a $\mathrm{C}_{\mathrm{q}}$ ratio of 1.13. When only the $\mathrm{CRH}$ samples were included, the msa/NFQ assay had a greatly increased geometric mean quantity $\left(1.9 \times 10^{7}\right)$ and the $\mathrm{C}_{\mathrm{q}}$ ratio declined to 0.82 , suggesting that it performed better among these samples, almost all of which had ELISA ODs $>1.2$ (Table 5). The cause of this result is uncertain; the CRH samples were from heavily infected fish that were likely to contain Renibacterium salmoninarum strains with multiple msa gene copies, which could account for their virulence (Coady et al. 2006) and may explain the increase in amplification. However, log scale differences in gene quantity which may be attributable to multiple copies of the msa gene would still only result in minor changes in the resulting $\mathrm{C}_{\mathrm{q}}$ value. These 2 assays are currently undergoing testing in fish experimentally injected with $R$. salmoninarum (thus with known infection levels), and that investigation may clarify these results (D. Elliott \& M. Purcell pers. comm.).

This study was not designed to compare the nPCR to the $3 \mathrm{qPCR}$ primer and probe sets. Instead of testing a mix of known positive and negative fish, we first screened the samples by $\mathrm{nPCR}$ because they were naturally exposed and their infection prevalence and severity were unknown. This precluded us from calculating either diagnostic sensitivity or specificity, as outlined in the World Organization for Animal Health (OIE) manual (Jacobson \& Wright 2006). Under OIE guidelines, the ideal test of intra-assay variance would have been performed using true replicates from each fish, with each separate $25 \mathrm{mg}$ kidney sample undergoing individual sample processing and DNA extraction. However, the small mass of kidney tissue available precluded that approach in this study, and the replicates we used were drawn from the same original sample of kidney tissue (i.e. 1 tube of DNA from each fish, rather than multiple tubes of DNA from each fish). The use of plasmids to serve as positive controls to generate standard curves in the qPCRs likely also resulted in an underestimation of the actual number of gene copies detected, as the plasmid amplifies more readily than genomic Renibacterium salmoninarum DNA (T. A. Sandell pers. obs.). However, the use of a plasmid that may be widely distributed among fish health laboratories provides a useful standard that removes the need for each laboratory to produce and quantify its own bacterial genomic DNA standards, removing a potential source of error. 


\section{CONCLUSIONS}

Newer molecular techniques for the detection and quantification of pathogenic bacteria in fish are being developed, including DNA microarrays coupled with PCR (Call et al. 2003, Warsen et al. 2004), multiplex qPCR (at present, none have included Renibacterium salmoninarum in their panels; see Ji et al. 2004, Panangala et al. 2007), and the newer technique of loopmediated isothermal amplification (Gahlawat et al. 2009). Eventually, a newly developed assay will surpass those currently available. However, without studies to evaluate and compare these protocols they are of limited use, and at present there is confusion about which assay is most appropriate and an inability to compare data between investigations.

Ideally, researchers in a given area (e.g. the Columbia River basin), or even a given region (e.g. the Pacific Northwest, USA), should be able to agree on using at least one common assay in all related studies, or to archive samples (or DNA) whenever possible for future comparative testing. This would immediately improve our understanding of how this pathogen affects the growth, survival and fitness of salmonid populations in regions where Renibacterium salmoninarum is widely endemic. At present, there is no 'gold standard' assay for the detection and quantification of $R$. salmoninarum; for example, other authors have also demonstrated that samples may be ELISA positive and nPCR negative (Faisal \& Eissa 2009). While the present study is a step towards this goal, we are unable to recommend one molecular assay as the single best diagnostic assay for $R$. salmoninarum; as a result, 2 or more assays may be necessary to meet the goals of a specific project. However, both the msa/NFQ and $a b c / N F Q$ qPCR assays evaluated here do have utility in specific applications, as outlined above. It is our hope that this study will provide the first step in the selection of a common assay for $R$. salmoninarum detection and quantification.

Acknowledgements. We thank M. Purcell (USGS Western Fisheries Research Center, Seattle, Washington) for providing most of the bacterial seed stocks for the cross-reactivity study, as well as assistance with troubleshooting the msa/NFQ qPCR assay and for her thorough review, which greatly improved this manuscript. We also thank L. Lindsay (Oregon Department of Fish and Wildlife, Fish Health Division, Corvallis, Oregon) for her assistance with the ELISA and, together with C. Banner and T. Amandi (ODFW), for providing the Cole River Hatchery samples and for sharing their knowledge of Renibacterium salmoninarum. We thank L. Rhodes (NOAA, NWFSC, Seattle, Washington) for her advice on optimization of the $a b c$ qPCR assay and for the $a b c$ gene plasmid, as well as reviewing the manuscript, and K. True (US Fish and Wildlife Service, California-Nevada Fish Health Center, Anderson, California) for providing the msa plasmid and for organizing the first fish health pathogen qPCR workshop in 2006. We also thank J. Bartholomew (Department of Microbi- ology, Oregon State University, Corvallis, Oregon) and E. Casillas (NOAA/NWFSC, Seattle, Washington) for reviewing, and improving, this manuscript. We also acknowledge M. B. Rew (CIMRS, Oregon State University, Newport, Oregon) for her able assistance in the laboratory, J. Krenz (formerly of USDA, Newport, Oregon) for instruction on the PicoGreen assay and the correct usage of the Biomek robot, and black rockfish angler extraordinaire J. Losee for providing negative control kidneys. This study was funded in part by the Mamie Markham Research Fund, administered through the Hatfield Marine Science Center (Oregon State University), and by the Bonneville Power Administration.

\section{LITERATURE CITED}

AFS-FHS (2007) Model quality assurance/quality control program for fish health laboratories. In: AFS Fish Health Section (ed): The blue book. American Fisheries Society, Bethesda, MD, p 1-16

Alcorn S, Murray AL, Pascho RJ, Varney J (2005) A cohabitation challenge to compare the efficacies of vaccines for bacterial kidney disease (BKD) in chinook salmon Oncorhynchus tshawytscha. Dis Aquat Org 63:151-160

Balfry SK, Albright LJ, Evelyn TPT (1996) Horizontal transfer of Renibacterium salmoninarum among farmed salmonids via the fecal-oral route. Dis Aquat Org 25:63-69

Belak S, Thoren P (2006) Validation and quality control of polymerase chain reaction methods for the diagnosis of infectious diseases. In: Manual of diagnostic tests for aquatic animals. World Organization for Animal Health (Office International des Epizooties), Paris, p 24-30

- Bruno D, Collet B, Turnbull A, Kilburn R and others (2007) Evaluation and development of diagnostic methods for Renibacterium salmoninarum causing bacterial kidney disease (BKD) in the UK. Aquaculture 269:114-122

$>$ Bustin SA, Benes V, Garson JA, Hellemans J and others (2009) The MIQE guidelines: minimum information for publication of quantitative real-time PCR experiments. Clin Chem 55:611-622

Call DR, Borucki MK, Loge FJ (2003) Detection of bacterial pathogens in environmental samples using DNA microarrays. J Microbiol Methods 53:235-243

Chase DM, Pascho RJ (1998) Development of a nested polymerase chain reaction for amplification of a sequence of the p57 gene of Renibacterium salmoninarum that provides a highly sensitive method for detection of the bacterium in salmonid kidney. Dis Aquat Org 34:223-229

> Chase DM, Elliot DG, Pascho RJ (2006) Detection and quantification of Renibacterium salmoninarum DNA in salmonid tissues by real-time quantitative polymerase chain reaction analysis. J Vet Diagn Invest 18:375-380

> Coady AM, Murray AL, Elliott DG, Rhodes LD (2006) Both msa genes in Renibacterium salmoninarum are needed for full virulence in bacterial kidney disease. Appl Environ Microbiol 72:2672-2678

> Faisal M, Eissa AE (2009) Diagnostic testing patterns of Renibacterium salmoninarum in spawning salmonid stocks in Michigan. J Wildl Dis 45:447-456

Gahlawat SK, Ellis AE, Collet B (2009) A sensitive loop-mediated isothermal amplification (LAMP) method for detection of Renibacterium salmoninarum, causative agent of bacterial kidney disease in salmonids. J Fish Dis 32:491-497

Gudmundsdóttir S, Benediktsdóttir E, Helgason S (1993) Detection of Renibacterium salmoninarum in salmonid kidney samples - a comparison of results using doublesandwich ELISA and isolation on selective medium. J Fish Dis 16:185-195 
Halaihel N, Vendrell D, Ruiz-Zarzuela I, de Blas I and others (2009) A new real time PCR-based assay for diagnosing Renibacterium salmoninarum in rainbow trout (Oncorhynchus mykiss) and comparison with other techniques. J Microbiol Methods 76:75-80

Jacobson R, Wright P (2006) Principles of validation of diagnostic assays for infectious diseases. In: Manual of diagnostic tests for aquatic animals. World Organization for Animal Health (Office International des Epizooties), Paris, p 11-22

Jansson E, Hongslo T, Höglund J, Ljungberg O (1996) Comparative evaluation of bacterial culture and two ELISA techniques for the detection of Renibacterium salmoninarum antigens in salmonid kidney tissues. Dis Aquat Org 27:197-206

Jansson E, Lindberg L, Saker E, Aspan A (2008) Diagnosis of bacterial kidney disease by detection of Renibacterium salmoninarum by real-time PCR. J Fish Dis 31:755-763

Ji N, Peng B, Wang G, Wang S, Peng X (2004) Universal primer PCR (UPPCR) with DGGE for rapid detection of bacterial pathogens. J Microbiol Methods 57:409-413

> Josephson KL, Gerba CP, Pepper IL (1993) Polymerase chain reaction detection of nonviable bacterial pathogens. Appl Environ Microbiol 59:3513-3515

Kaattari IM, Piganelli JD (1997) Immunization with bacterial antigens: bacterial kidney disease. In: Gudding R, Lillehaug A, Midtlyng $\mathrm{P}$, Brown $\mathrm{F}$ (eds) Fish vaccinology. Karger, Oslo, p 145-152

Kim WS, Nishizawa T, Yoshimizu M (2007) Non-specific adsorption of fish immunoglobulin $\mathrm{M}$ ( $\mathrm{IgM}$ ) to blocking reagents on ELISA plate wells. Dis Aquat Org 78:55-59

McKibben CL, Pascho RJ (1999) Shedding of Renibacterium salmoninarum by infected Chinook salmon Oncorynchus tshawytscha. Dis Aquat Org 38:75-79

Miriam A, Griffiths SG, Lovely JE, Lynch WH (1997) PCR and probe-PCR assays to monitor broodstock Atlantic salmon (Salmo salar L) ovarian fluid and kidney tissue for presence of DNA of the fish pathogen Renibacterium salmoninarum. J Clin Microbiol 35:1322-1326

Mitchum DL, Sherman LE (1981) Transmission of bacterial kidney disease from wild to stocked hatchery trout. Can J Fish Aquat Sci 38:547-551
Panangala VS, Shoemaker CA, van Santen VL, Dybvig K, Klesius PH (2007) Multiplex-PCR for simultaneous detection of 3 bacterial fish pathogens, Flavobacterium columnare, Edwardsiella ictaluri, and Aeromonas hydrophila. Dis Aquat Org 74:199-208

Pascho RJ, Mulcahy D (1987) Enzyme-linked immunosorbent assay for soluble antigen of Renibacterium salmoninarum, the causative agent of bacterial kidney disease. Can J Fish Aquat Sci 44:183-191

Pascho RJ, Goodrich TD, McKibben CL (1997) Evaluation by enzyme-linked immunosorbent assay (ELISA) of Renibacterium salmoninarum bacterins affected by persistence of bacterial antigens. J Aquat Anim Health 9:99-107

> Piganelli JD, Wiens GD, Zhang JA, Christensen JM, Kaattari SL (1999) Evaluation of a whole cell, p57- vaccine against Renibacterium salmoninarum. Dis Aquat Org 36: $37-44$

Powell M, Overturf K, Hogge C, Johnson K (2005) Detection of Renibacterium salmoninarum in Chinook salmon, Oncorhynchus tshawytscha (Walbaum), using quantitative PCR. J Fish Dis 28:615-622

Rhodes LD, Coady AM, Deinhard RK (2004) Identification of a third msa gene in Renibacterium salmoninarum and the associated virulence phenotype. Appl Environ Microbiol 70:6488-6494

Rhodes LD, Durkin C, Nance SL, Rice CA (2006) Prevalence and analysis of Renibacterium salmoninarum infection among juvenile Chinook salmon Oncorhynchus tshawytscha in North Puget Sound. Dis Aquat Org 71: 179-190

Suzuki K, Sakai DK (2007) Real-time PCR for quantification of viable Renibacterium salmoninarum in chum salmon Oncorhynchus keta. Dis Aquat Org 74:209-223

Warsen AE, Krug MJ, LaFrentz S, Stanek DR, Loge FJ, Call DR (2004) Simultaneous discrimination between 15 fish pathogens by using 16S ribosomal DNA PCR and DNA microarrays. Appl Environ Microbiol 70:4216-4221

> Wood PA, Wiens GD, Rohovec JS, Rockey DD (1995) Identification of an immunologically cross-reactive 60-kilodalton Renibacterium salmoninarum protein distinct from p57: Implications for immunodiagnostics. J Aquat Anim Health $7: 95-103$

Appendix 1. Comparison of inter-plate (a) $C_{q}$ values and (b) mean quantities for $a b c$ gene detection in repeatability tests of 6 nested PCR positive samples using the $a b c$ gene primers/MGB probe. p-values for significant differences between plates were calculated via the Kruskal-Wallis non-parametric ANOVA. GM: geometric mean; CV: coefficient of variation

\begin{tabular}{|c|c|c|c|c|c|c|c|c|c|c|c|c|}
\hline \multirow{2}{*}{$\begin{array}{l}\text { Sample } \\
\text { ID }\end{array}$} & & \multirow{2}{*}{ n/plate } & \multirow{2}{*}{$\begin{array}{c}\% \\
\text { positive }\end{array}$} & \multicolumn{2}{|c|}{ Plate 1} & \multicolumn{2}{|c|}{ Plate 2} & \multicolumn{2}{|c|}{ Plate 3} & \multicolumn{2}{|c|}{ All 3 plates } & \multirow{2}{*}{$\mathrm{p}$} \\
\hline & & & & GM & $\mathrm{CV}$ & GM & $\mathrm{CV}$ & GM & $\mathrm{CV}$ & GM & $\mathrm{CV}$ & \\
\hline \multicolumn{13}{|l|}{ a) $\mathrm{C}_{\mathrm{q}}$} \\
\hline 2893 & Sample 1 & 6 & 100 & 19.8 & 0.088 & 19.6 & 0.095 & 19.7 & 0.101 & 19.7 & 0.091 & 0.45 \\
\hline 5332 & Sample 2 & 8 & 100 & 35.8 & 0.017 & 34.4 & 0.088 & 33.8 & 0.082 & 34.6 & 0.069 & 0.83 \\
\hline 5609 & Sample 3 & 6 & 100 & 31.9 & 0.093 & 31.6 & 0.089 & 31.2 & 0.074 & 31.6 & 0.081 & 0.78 \\
\hline 5697 & Sample 4 & 6 & 100 & 19.9 & 0.027 & 19.7 & 0.028 & 19.7 & 0.027 & 19.7 & 0.026 & 0.72 \\
\hline 5723 & Sample 5 & 4 & 100 & 18.4 & 0.012 & 18.2 & 0.01 & 18.4 & 0.01 & 18.3 & 0.011 & 0.31 \\
\hline 9249 & Sample 6 & 6 & 100 & 19.9 & 0.103 & 19.6 & 0.1 & 19.8 & 0.102 & 19.7 & 0.096 & 0.62 \\
\hline \multicolumn{13}{|c|}{ b) Quantity } \\
\hline 2893 & Sample 1 & 6 & 100 & 62490.7 & 1.04 & 62307.1 & 1.1 & 58753.5 & 1.16 & 61159.3 & 1.06 & 0.91 \\
\hline 5332 & Sample 2 & 8 & 100 & 1.0 & 0.395 & 1.6 & 1.6 & 3.3 & 1.42 & 1.5 & 1.79 & 0.22 \\
\hline 5609 & Sample 3 & 6 & 100 & 13.3 & 0.95 & 9.5 & 0.9 & 20.0 & 0.8 & 13.6 & 0.86 & 0.48 \\
\hline 5697 & Sample 4 & 6 & 100 & 61643.6 & 0.36 & 62019.1 & 0.38 & 62604.2 & 0.34 & 62087.7 & 0.34 & 0.99 \\
\hline 5723 & Sample 5 & 4 & 100 & 172320.9 & 0.15 & 185654.6 & 0.13 & 151541.2 & 0.12 & 169248.5 & 0.15 & 0.14 \\
\hline 9249 & Sample 6 & 6 & 100 & 57757.4 & 0.97 & 63593.0 & 1.02 & 55696.9 & 1 & 58922.7 & 0.94 & 0.86 \\
\hline
\end{tabular}

